\title{
PELATIHAN KETANGGUHAN UNTUK MENINGKATKAN KESEJAHTERAAN PSIKOLOGIS PENGURUS UNIT KEGIATAN MAHASISWA (UKM) DI UNIVERSITAS SURABAYA
}

\author{
Jessica Christina Widhigdo ${ }^{1}$, Joshua Michael Ahuluheluw, \& Lena Nessyana Pandjaitan \\ Magister Psikologi Profesi, Universitas Surabaya, Jalan Raya Kalirungkut 60293, Surabaya, Indonesia
}

Korespondensi:

le-mail: jess16cw@gmail.com

\begin{abstract}
Involvement in various organizational activities may positively or negatively affect students' psychological well-being (PWB). Hardiness, which involves commitment, control, and openness towards challenges, is the psychological trait that is considered essential for an effective problem solving, and is believed to be necessary in order to take the most positive advantage of organizational involvement. The present study aimed to examine the changes in the PWB scores of students who were involved in organizational activities after undergoing hardiness training; it also aims at exploring the relationship between hardiness and PWB. Participants were 20 university students aged 18 to 22 years old who were involved in student organizations. Quantitative data analysis was conducted using Wilcoxon and Spearman nonparametric tests. Results showed that there was a significant increase in the PWB scores after participating in the hardiness training. The study also found a positive correlation between hardiness and PWB.
\end{abstract}

Article history:

Received 19 August 2019

Received in revised form 21 October 2019

Accepted 4 November 2019

Available online 8 February 2020

\section{Keywords:}

hardiness;

PWB;

student organization activities;

training

\begin{abstract}
Abstrak - Kegiatan berorganisasi dapat membawa dampak positif dan negatif terhadap kesejahteraan psikologis mahasiswa (psychological well being; PWB). Kepribadian tangguh yang terdiri dari komitmen, kontrol, dan terbuka terhadap tantangan dibutuhkan untuk menghadapi masalah dengan efektif, sehingga dapat memberi manfaat positif dalam keikutsertaan berorganisasi. Penelitian ini bertujuan untuk mengetahui perubahan PWB mahasiswa setelah mengikuti pelatihan ketangguhan dan mengeksplorasi keterkaitan antara ketangguhan dan PWB. Partisipan ialah 20 mahasiswa (18-22 tahun) yang terlibat sebagai pengurus UKM. Analisis data kuantitatif dilakukan menggunakan analisis non-parametrik Wilcoxon dan Spearman. Hasil penelitian ini menemukan bahwa terdapat peningkatan skor PWB pada pengurus UKM setelah mengikuti pelatihan ketangguhan, dan terdapat korelasi positif antara ketangguhan dan PWB.
\end{abstract}

Kata Kunci: kesejahteraan psikologis; ketangguhan; pelatihan; Unit Kegiatan Mahasiswa 


\section{PENDAHULUAN}

Kesejahteraan psikologis (psychological well-being; PWB) merupakan evaluasi individu mengenai peristiwa yang terjadi dalam hidup yang dapat menghasilkan perasaan dan pemikiran yang positif atau negatif (Ryff, 1989). PWB merupakan aspek penting bagi individu. Individu dengan tingkat PWB yang tinggi akan memiliki pemikiran terhadap masa depan yang lebih positif (Garcia \& Siddiqui, 2009) dan menghasilkan emosi yang positif. Proctor, Linley, dan Maltby (2009) menjelaskan bahwa pemikiran atau persepsi individu mengenai masa depan berkaitan dengan berkurangnya keinginan untuk bunuh diri, penggunaan narkoba, dan kekerasan pada remaja hingga dewasa (Jayervand, Ahdi, Mazaheri, Talebi, \& Manshaee, 2013). PWB yang tinggi membantu individu untuk merasakan emosi dan perspektif positif tentang masa depan, serta mengurangi rasa cemas dan stres yang diakibatkan oleh padatnya beban kerja yang dimiliki (Suleman, Hussain, Shehzad, Syed, \& Raja, 2018). Berdasarkan pemaparan di atas, dapat disimpulkan bahwa PWB berdampak bagi mahasiswa (Freire, Ferradás, Valle, Núñez, \& Vallejo, 2016).

Kegiatan berorganisasi memberikan dampak positif bagi mahasiswa, yaitu berkaitan dengan kecerdasan emosional (Cahyaningtyas, 2010). Namun, beberapa penelitian menemukan bahwa keikutsertaan dalam organisasi memberikan dampak negatif, yaitu permasalahan konsentrasi, waktu, tenaga, dan menimbulkan stres pada mahasiswa, sehingga tugas perkuliahan atau organisasi menjadi terbengkalai dan tertunda (Anggoro, 2016; Beleaua \& Cocoradă, 2016; Hussain \& Sultan, 2010). Mayasari (2007) menemukan bahwa proses penundaan (prokrastinasi) oleh pengurus organisasi dilakukan secara sengaja. Prokrastinasi terjadi karena kemampuan pengelolaan waktu dan prioritas yang kurang bijaksana. Mahasiswa yang berkuliah sambil aktif berorganisasi atau bekerja memiliki beban kerja dan tingkat stres yang lebih tinggi dibandingkan dengan mahasiswa pada umumnya (Amiruddin, 2017; Sahari, Yaman, \& Awang-Shuib, 2012). Stres tinggi pada mahasiswa akan memengaruhi PWB dan relasi interpersonal (Ofori, Addai, Avor, \& Quaye, 2018; Suleman dkk., 2018; Yikealo, Tareke, \& Karvinen, 2018).

Hasil wawancara pada bulan Maret 2019 kepada 10 pengurus unit kegiatan mahasiswa (UKM), 1 pembina organisasi, dan 5 pengurus periode sebelumnya menunjukkan bahwa terdapat beberapa aspek PWB yang perlu ditingkatkan, yaitu: 1). Mahasiswa kurang memiliki tujuan, harapan, dan cita-cita (purpose in life) dalam menyelesaikan tugas dan kewajibannya karena ketidakpedulian terhadap jadwal pengumpulan tugas yang dimiliki; 2). Kurangnya kemampuan 
pengurus UKM dalam menjalin hubungan yang hangat, penuh kepercayaan, kemampuan menunjukkan empati dan afeksi (positive relation with others), serta kepedulian terhadap kesejahteraan orang lain, sehingga muncul banyak konflik antar pengurus; 3). Kurangnya kemampuan pengurus UKM dalam mengendalikan lingkungan (environmental mastery), di mana pengurus UKM paduan suara sulit untuk mengatur waktu antara tugas dan tanggung jawab perkuliahan dan UKM, sehingga pengurus kurang memiliki kontrol dan kendali terhadap lingkungan sekitar; 4). Kurangnya kemampuan pengurus UKM dalam menentukan atau mengambil keputusan secara mandiri (autonomy), di mana pengurus UKM masih meminta bantuan kepada pembina dan ketua ketika menghadapi kesulitan; dan 5). Pengurus UKM kurang memiliki sikap terbuka terhadap tantangan atau pengalaman baru, sehingga perkembangan menjadi pribadi yang lebih baik menjadi kurang optimal (personal growth). Pengurus UKM cenderung mengalami stagnansi dan kurang memiliki sikap dewasa dalam penyelesaian tugas dan tanggung jawabnya.

Penjelasan di atas menunjukkan bahwa padatnya beban tugas dalam perkuliahan yang ditambah dengan kegiatan organisasi kemahasiswaan dapat memengaruhi PWB (Amiruddin, 2017; Ofori dkk., 2018; Sahari dkk., 2012). Hal tersebut menyebabkan PWB pengurus UKM perlu ditingkatkan agar dapat berfungsi lebih optimal. Salah satu cara untuk meningkatkan PWB adalah melalui pelatihan ketangguhan. Nayyeri dan Aubi (2011) menemukan bahwa ketangguhan dapat memprediksi $38.1 \%$ terhadap kesejahteraan seseorang. Persentase ini membuktikan bahwa peningkatan atau penurunan ketangguhan memiliki jenis yang signifikan kaitannya dengan kesejahteraan. Penelitian ini menjelaskan bahwa ketangguhan mampu meningkatkan kesehatan, kebahagiaan, mengurangi emosi negatif, dan munculnya emosi positif terhadap kehidupan. Pemilihan ketangguhan dilakukan sesuai dengan analisis kebutuhan dan hasil wawancara, yaitu kurangnya komitmen pada pengurus, sehingga menunjukkan sikap tidak peduli terhadap tugas dan agenda yang telah ditetapkan organisasi (purpose in life), serta kurangnya kontrol yang dimiliki pengurus terhadap lingkungan dan waktu, sehingga berdampak pada positive relation with other, environmental mastery, dan autonomy, serta kurang terbuka pada tantangan yang baru.

Kobasa (Skomorovsky \& Sudom, 2011) mendefinisikan ketangguhan sebagai karakteristik kepribadian yang menyebabkan individu mampu bertahan dalam menghadapi situasi yang tidak menyenangkan. Individu dengan ketangguhan yang tinggi dicirikan dengan adanya kontrol, komitmen, dan terbuka terhadap tantangan.

Pelatihan ketangguhan ini terdiri dari enam sesi berdasarkan aspek-aspek dari ketangguhan. Tema pelatihan yang diberikan berupa pelatihan dalam rangka meningkatkan PWB peserta terkait 
banyaknya beban tugas perkuliahan dan organisasi. Pelatihan akan diberikan melalui pembekalan konsep teoretis maupun kemampuan praktis mengenai ketangguhan untuk menumbuhkan kesadaran akan pentingnya kontrol diri dan komitmen dalam menghadapi tantangan atau situasi yang tidak menyenangkan.

\section{Psychological Well-Being}

Psychological Well-Being (PWB) merupakan keadaan di mana seseorang berusaha untuk berpikir positif tentang diri sendiri dan menyadari keterbatasan yang dimiliki. Individu mampu menerima keadaan dirinya, menjalin hubungan yang hangat dengan orang lain, mandiri, menciptakan situasi yang sesuai dengan keadaan psikisnya, mempunyai tujuan hidup yang jelas, serta mampu mengembangkan potensinya secara terus-menerus (Ryff, 1989). Hal tersebut mampu membantu individu untuk membentuk lingkungan yang dapat memenuhi kebutuhan dan keinginan pribadi. PWB terdiri dari enam aspek, yaitu penerimaan diri, hubungan positif dengan orang lain, otonomi, penguasaan lingkungan, tujuan hidup, dan pertumbuhan pribadi. Ryff (1989) menjelaskan terdapat tujuh faktor yang dapat memengaruhi PWB seseorang, yaitu usia, jenis kelamin, budaya, religiusitas, dukungan sosial, kepribadian, dan stres.

\section{Ketangguhan}

Konsep ketangguhan (hardiness) pertama kali dikenalkan oleh Kobasa (Sandvik, Hansen, Hystad, Johnsen, \& Bartone, 2015) yang menjelaskan bahwa individu tetap berada dalam kondisi "sehat", meskipun tingkat stres kerja yang dimiliki tergolong tinggi. Sandvik dkk. (2015) mengungkapkan bahwa ketangguhan dapat melindungi diri dari efek negatif stres pada fisik dan kesehatan mental. Orang yang tangguh lebih berkomitmen dalam menjalani kehidupan sehari-hari dan memandang perubahan dan kesulitan dalam hidup sebagai tantangan daripada sebagai pemicu stres. (Skomorovsky \& Sudom, 2011). Berdasarkan uraian di atas, dapat disimpulkan bahwa ketangguhan adalah upaya individu untuk bertahan dan mengontrol kondisi internal dalam menghadapi tekanan, sehingga dapat terhindar dari segala dampak negatif yang muncul akibat stres.

Terdapat tiga dimensi dari ketangguhan (Skomorovsky \& Sudom, 2011; Sandvik dkk., 2015), yaitu komitmen, kontrol, dan tantangan. Komitmen merupakan kemampuan untuk terlibat dalam segala aktivitas dalam hidup. Kontrol merupakan sebuah keyakinan yang dapat mengendalikan atau memengaruhi pengalaman individu. Melalui keyakinan ini, individu memiliki kuasa untuk mengontrol berbagai peristiwa dan pengalaman hidupnya. Tantangan adalah perasaan 
individu dalam mengantisipasi berbagai perubahan sebagai sesuatu hal yang menantang untuk perkembangan yang lebih jauh. Dapat dikatakan bahwa individu yang memiliki sudut pandang yang berbeda dalam menanggapi perubahan adalah individu yang menganggap bahwa tantangan inilah yang mampu membawa pertumbuhan dan perkembangan dalam dirinya.

\section{Ketangguhan dan Psychological Well-Being}

Ketangguhan memberikan efek secara langsung terhadap PWB seseorang ketika berada di bawah terkanan atau situasi yang penuh dengan stres (Skomorovsky \& Sudom, 2011). Penelitian Nayyeri dan Aubi (2011) menjelaskan bahwa ketangguhan memprediksi 38.1\% dan komponen kontrol dari ketangguhan memperediksi $36.7 \%$ dari PWB. Ketangguhan dapat meningkatkan kesehatan, kebahagiaan, mengurangi emosi-emosi yang tidak menyenangkan, serta meningkatkan munculnya emosi-emosi positif terhadap kehidupan, kesejahteraan, dan PWB (Cerezo, Galian, Tarroja, Mañalac, \& Ysmael, 2015).

Tujuan penelitian ini adalah untuk mengetahui apakah terdapat perbedaan PWB peserta antara sebelum dan sesudah mengikuti pelatihan ketangguhan. Selain itu, berdasarkan pemaparan sebelumnya, ketangguhan dan PWB memiliki keterkaitan. Oleh karena itu, hipotesis penelitian ini adalah terdapat perbedaan skor PWB pada pengurus UKM antara sebelum dan sesudah mengikuti pelatihan ketangguhan, serta terdapat hubungan yang signifikan antara ketangguhan dan PWB pada pengurus UKM.

\section{METODE}

\section{Partisipan}

Peserta dalam pelatihan ini adalah 20 mahasiswa pengurus Unit Kegiatan Mahasiswa (UKM) Paduan Suara 2018-2019 di Universitas Surabaya dengan rentang usia 18-22 tahun. Pemilihan UKM Paduan Suara sebagai partisipan adalah dikarenakan dibandingkan dengan seluruh unit kegiatan mahasiswa di Universitas Surabaya, UKM Paduan Suara merupakan UKM dengan beban yang berat karena mengharuskan adanya latihan, meliputi latihan secara fisik, vokal, dan rapat rutin. Pemilihan partisipan dilakukan dengan metode purposive non-random sampling. Kriteria yang digunakan adalah partisipan merupakan pengurus UKM Paduan Suara, berusia 18-22 tahun, dan memiliki skor $P W B$ pada kategori sedang dan rendah. 


\section{Desain}

Desain penelitian yang digunakan adalah quasi-experimental dengan one group pretestposttest design, yaitu dengan membandingkan skor antara sebelum dan sesudah mengikuti pelatihan (Sugiyono, 2004). Penelitian ini tidak menggunakan kelompok kontrol atau kelompok pembanding. Pada penelitian ini, partisipan akan diberikan pelatihan ketangguhan. Sebelum dan sesudah mengikuti pelatihan, partisipan akan diberikan pretest dan posttest. Variabel yang tidak berhubungan dengan penelitian dikontrol melalui pengendalian faktor yang dapat memengaruhi PWB, yaitu usia dan status ekonomi yang dapat memengaruhi dukungan sosial.

Tabel 1.

Desain Penelitian One Group Pretest-Posttest

\begin{tabular}{ccc}
\hline Pretest & Treatment & Posttest \\
\hline $\mathrm{O}_{1}$ & $\mathrm{X}$ & $\mathrm{O}_{2}$ \\
\hline
\end{tabular}

\section{Prosedur}

Penelitian ini diawali dengan melakukan penggalian data partisipan. Selanjutnya, partisipan mengikuti pelatihan yang terdiri dari enam sesi dan terbagi menjadi dua hari.

Hari pertama terdiri dari sesi 1 dan 2 yang mengajarkan peserta cara untuk mengontrol diri, dimulai dari mengontrol perilaku diri sendiri sampai mengontrol emosi pada lingkungan (aspek kontrol). Aspek kontrol dapat memenaruhi peningkatan PWB, yaitu aspek kemandirian, penguasaan lingkungan, tujuan, dan hubungan positif dengan orang lain (De Ridder, Lensvelt-Mulders, Finkenauer, Stok, \& Baumeister, 2012; Finkel \& Campbell, 2001; Kobasa, Maddi, \& Kahn, 1982; Righetti \& Finkenauer, 2011; Tangney, Baumeister, \& Boone, 2004).

Hari kedua terdiri dari sesi 3 sampai 6 . Sesi 3 dan 4 mengajarkan peserta pentingnya komitmen diri dan kelompok atau organisasi (aspek komitmen). Aspek komitmen dapat memengaruhi peningkatan PWB yang berkaitan dengan aspek hubungan positif dengan orang lain, tujuan, dan pertumbuhan pribadi (Kobasa dkk., 1982; Maltin, 2011). Sesi 5 dan 6 mengajarkan peserta cara untuk menghadapi tantangan atau situasi yang tidak menyenangkan dalam hidup, terutama dalam perkuliahan dan organisasi (aspek tantangan). Salah satu metode yang digunakan dalam sesi 5 dan 5 adalah SWOT. Individu yang berani menghadapi tantangan dan beranggapan bahwa tantangan merupkan kesempatan untuk bertumbuh dan berkembang merupakan individu yang dapat mengendalikan lingkungan (environmental mastery), memiliki kemandirian dalam 
bertindak (autonomy), memiliki tujuan (purpose in life), serta memiliki keinginan untuk terus bertumbuh dan berkembang menjadi pribadi yang lebih baik lagi (personal growth) (Bonanno, 2004; Mathis \& Lecci, 1999). Peserta dapat memahami keterkaitan antara aspek tantangan dengan aspek $P W B$ melalui analisa SWOT (strength, weakness, oppurtunities, dan threat) dan metode relaksasi sebagai bentuk coping strategy. SWOT merupakan identifikasi berbagai faktor secara sistematis untuk merumuskan strategi penyelesaian masalah yang terdiri dari memaksimalkan kekuatan (strength) dan peluang (oppurtunities), dan secara bersamaan meminimalisasi kelemahan (weakness) dan ancaman (threats) (Rangkuti, 2004).

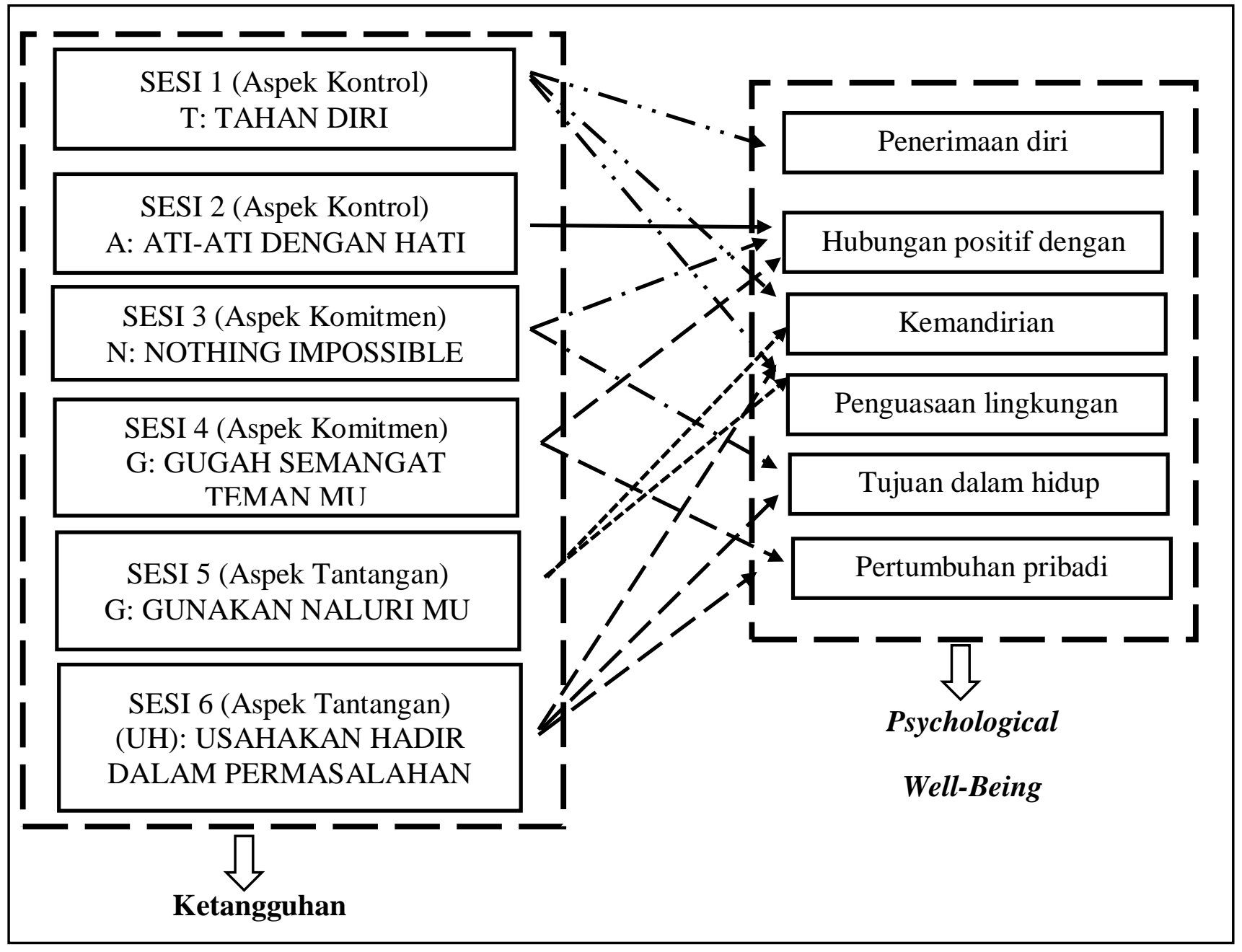

Figur 1. Skema Pelatihan Ketangguhan untuk Meningkatkan PWB

Setiap sesi berdurasi sekitar 90 menit. Sebelum dan sesudah mengikuti pelatihan, partisipan diminta untuk mengisi kuesioner, skala ketangguhan, dan skala $P W B$. Metode yang digunakan 
dalam pelatihan ini adalah lecturing, role play, audiovisual, discussion, games, dan case study. Prosedur yang dilakukan selama pelatihan dari sesi 1-6 dapat dilihat pada Tabel 2.

Tabel 2.

Prosedur Pelatihan

\begin{tabular}{|c|c|c|}
\hline Sesi & Aspek Ketangguhan & Uraian Kegiatan \\
\hline $\begin{array}{c}\mathrm{I} \\
\mathrm{T}=\text { Tahan diri }\end{array}$ & \multirow{2}{*}{ Kontrol } & $\begin{array}{l}\text { Pemberian penjelasan mengenai pentingnya kontrol } \\
\text { terhadap diri melalui pemutaran video klip dan secara } \\
\text { verbal, cara-cara yang dapat dilakukan untuk } \\
\text { mengaplikasikan kontrol terhadap diri sendiri dan } \\
\text { manfaatnya dalam kehidupan sehari-hari, serta } \\
\text { kaitannya dengan PWB. }\end{array}$ \\
\hline $\begin{array}{c}\mathrm{II} \\
\mathrm{A}: \text { Ati-Ati dengan } \\
\text { Hati }\end{array}$ & & $\begin{array}{l}\text { Pemberian penjelasan mengenai pentingnya kontrol } \\
\text { terhadap emosi melalui pemutaran video klip dan } \\
\text { secara verbal, role play, cara-cara yang dapat } \\
\text { dilakukan untuk mengontrol emosi (relaksasi), dan } \\
\text { manfaatnya dalam kehidupan sehari-hari kaitannya } \\
\text { dengan PWB. }\end{array}$ \\
\hline $\begin{array}{l}\text { III } \\
\mathrm{N} \text { : Nothing is } \\
\text { impossible }\end{array}$ & \multirow{2}{*}{ Komitmen } & $\begin{array}{l}\text { Pemberian materi tentang pentingnya komitmen } \\
\text { terhadap diri sendiri dan memperkenalkan konsep } \\
\text { SMART (specific, measurable, attainable, reachable, } \\
\text { time-able) pada peserta. }\end{array}$ \\
\hline $\begin{array}{l}\text { IV } \\
\text { G: Gugah } \\
\text { semangat } \\
\text { temanmu }\end{array}$ & & $\begin{array}{l}\text { Pemberian materi tentang pentingnya komitmen dalam } \\
\text { kelompok dan membuat SMART untuk mencapai } \\
\text { tujuan kelompok. }\end{array}$ \\
\hline $\begin{array}{l}\mathrm{V} \\
\text { G: Gunakan } \\
\text { nalurimu }\end{array}$ & \multirow[b]{2}{*}{ Tantangan } & $\begin{array}{l}\text { Pemberian penjelasan mengenai pribadi yang tangguh } \\
\text { dalam mengambil keputusan secara mandiri, } \\
\text { pemberian materi mengenai proses hingga jenis-jenis } \\
\text { pengambilan keputusan (decisional making). }\end{array}$ \\
\hline $\begin{array}{l}\text { VI } \\
\text { UH: Usahakan } \\
\text { hadir dalam } \\
\text { permasalahan }\end{array}$ & & $\begin{array}{l}\text { Pemberian materi SWOT (strength, weakness, } \\
\text { opportunities, dan stress), analisa kasus, cara-cara } \\
\text { yang dapat dilakukan untuk mengatasi permasalahan } \\
\text { yang dihadapi (coping strategies), serta } \\
\text { memperkenalkan teknik relaksasi dalam menangani } \\
\text { stres (relaksasi otot, indera dan kognitif). }\end{array}$ \\
\hline
\end{tabular}

Evaluasi pelatihan dalam penelitian ini terbagi menjadi tiga, yaitu pada tataran reaksi (reaction), pembelajaran (learning), dan perilaku (behavior). Evaluasi reaksi dilakukan dengan menggunakan stik yang berisi skor untuk menilai pelaksanaan pelatihan yang meliputi panitia penyelenggara pelatihan, waktu, tempat, materi, dan metode yang diberikan dalam pelatihan. Evaluasi pada tingkat pembelajaran dilakukan menggunakan kuesioner yang berisi sejumlah pertanyaan pilihan ganda dan esai. Pertanyaan-pertanyaan yang diberikan berkaitan dengan materi yang disampaikan di setiap sesi pelatihan. Evaluasi behavior dilakukan melalui follow-up dengan 
metode wawancara dan pemberian angket setelah 3 minggu pelatihan. Pemberian angket dilakukan dengan menggunakan dua alat ukur, yakni alat ukur ketangguhan (Personal View Survey III-R) yang dikembangkan oleh Kobasa dan alat ukur $P W B$ yang dikembangkan oleh Ryff (1989). Alat ukur ketangguhan terdiri dari tiga aspek dengan total 18 butir dan terdiri dari empat pilihan jawaban (rentang 0 sampai 3). Alat ukur $P W B$ terdiri dari enam aspek dengan total 30 butir dan terdiri dari empat pilihan jawaban (rentang 1 sampai 4) dengan reliabilitas .85.

\section{Teknik Analisis}

Teknik analisis data yang digunakan dalam penelitian ini adalah uji beda non-parametrik, yaitu Wilcoxon dan uji korelasi non-parametrik, yaitu Spearman menggunakan SPSS for Windows versi 20.

\section{ANALISIS DAN HASIL}

Hasil evaluasi menunjukkan terdapat peningkatan pengetahuan antara sebelum $(M=54.05)$ dan sesudah $(M=74.23)$ mengikuti pelatihan. Hasil evaluasi dari skala ketangguhan menunjukkan bahwa ketangguhan dari peserta cenderung menetap setelah diberikan pelatihan $($ M pretest $=36.75$; $M$ posttest $=37.90)$. Terjadi peningkatan $P W B$ setelah diberikan pelatihan $(M$ pretest $=60.60 ; M$ posttest $=91.15)$.

Tabel 3.

Statistika Deskriptif Ketangguhan (Hardiness), PWB, dan Pengetahuan (Knowledge)

\begin{tabular}{lcccccccccc}
\hline & \multicolumn{4}{c}{ Sebelum Mengikuti Pelatihan } & \multicolumn{4}{c}{ Setelah Mengikuti Pelatihan } \\
\cline { 2 - 12 } & N & Min & Maks & $\boldsymbol{M}$ & SD & N & Min & Maks & M & SD \\
\hline Ketangguhan & 20 & 32 & 43 & 36.75 & 2.826 & 20 & 29 & 43 & 37.90 & 4.064 \\
PWB & 20 & 49 & 80 & 60.60 & 7.126 & 20 & 54 & 106 & 91.15 & 11.744 \\
\hline
\end{tabular}

Selanjutnya, hasil penelitian ini menunjukkan bahwa terdapat perbedaan yang signifikan antara skor PWB peserta antara sebelum dan sesudah mengikuti pelatihan $(M D=30.55 ; p=.000)$, namun hasil ini menunjukkan tidak terdapat perbedaan yang signifikan pada skor ketangguhan sebelum dan sesudah mengikuti pelatihan $(M D=1.15 ; p=.269)$. Dalam penelitian ini juga dilakukan uji korelasi yang menunjukkan adanya korelasi positif antara PWB dan ketangguhan $\left(r_{s}=\right.$ $.474 ; p=.035)$. 
Hasil analisis uji beda dari setiap aspek dari PWB menunjukkan bahwa terdapat perbedaan signifikan pada seluruh aspek sebelum dan sesudah mengikuti pelatihan $(p=.000-.001)$. Hasil analisis uji beda setiap aspek dari ketangguhan menunjukkan bahwa terdapat perbedaan signifikan pada aspek kontrol $(M D=-1.00 ; p=.042)$ dan komitmen $(M D=1,550 ; p=.005)$ sebelum dan sesudah mengikuti pelatihan, namun tidak terdapat perbedaan terhadap aspek tantangan $(M D=0.6$; $p=.334)$ antara sebelum dan sesudah mengikuti pelatihan.

\section{Evaluasi Lanjutan (Follow-Up)}

Hasil follow-up kuantitatif yang dilakukan pada 14 peserta menunjukkan bahwa tingkat kesejahteraan psikologis pada 2 peserta dapat dipertahankan serta pada 12 peserta lainnya mengalami penurunan setelah 3 minggu pemberian pelatihan. Sementara itu, tingkat ketangguhan peserta tidak mengalami peningkatan setelah 3 minggu pemberian pelatihan (10 orang tetap dan 4 orang mengalami penurunan).

Hasil evaluasi kualitatif yang dilakukan pada 5 orang menyatakan bahwa pada dasarnya peserta merasa pemberian materi yang diberikan sangat bermanfaat terhadap tugas dan tanggung jawab sebagai pengurus. Beberapa peserta sudah berusaha menerapkan teknik-teknik yang diajarkan dalam pelatihan, seperti relaksasi, serta pembuatan tabel SWOT dan SMART untuk menunjang penyelesaian tugas, namun beberapa peserta membutuhkan waktu yang lebih lama untuk beradaptasi dan mengubah kebiasaan yang telah dibangun selama bertahun-tahun. Berikut merupakan hasil wawancara dari peserta.

"Aku merasa sebenarnya sangat bermanfaat, tapi masih belum efektif ketika aku berusaha menjalankannya sendiri soalnya ya aku sulit ngubah kebiasaan lama ku. Tapi aku sudah berusaha menerapkan yang relaksasi, terus buat SWOT atau SMART tapi kadang masih lupa ya itu butuh waktu ya..."

"Setelah mengikuti pelatihan ini, aku merasa lebih komit dan tanggung jawab dalam menyelesaikan tugas kuliah dan juga organisasi, namun kadang ya masih naik turun. Aku merasa sekarang ini lebih mudah mengambil keputusan dan aku yakin sama keputusan itu dengan cara mempertimbangkan konsekuensikonsekuensi apa yang bisa diterima nanti. Tapi untuk beberapa strategi dan tekniknya memang belum, ada yang belum karena butuh waktu kadang juga lupa. Aku biasanya coba terapin yang relaksasi.." 
Pernyataan di atas merefleksikan bahwa beberapa strategi yang diberikan dalam pelatihan kurang sesuai dengan kebiasaan mereka dan merupakan sesuatu yang baru, sehingga cukup sulit untuk diterapkan dalam kehidupan sehari-hari.

\section{DISKUSI}

Pelatihan ketangguhan dapat meningkatkan skor PWB dan seluruh aspek PWB. Keberhasilan dari pelatihan ini sesuai dengan penelitian-penelitian terdahulu yang menyatakan bahwa ketangguhan memiliki korelasi dengan PWB (Skomorovsky \& Sudom, 2011; Nayyeri \& Aubi, 2011). Peningkatan PWB dapat terjadi karena dalam pelatihan ini terdapat peningkatan pengetahuan peserta mengenai ketangguhan. Individu dengan tingkat ketangguhan yang tinggi dapat mengobservasi dan mengantisipasi situasi yang tidak menyenangkan sebagai kesempatan untuk bertumbuh dan berkembang, sehingga berdampak pada kesehatan mental dan PWB (Alfred, Hammer, \& Good, 2014).

Ketangguhan merupakan proses belajar dan terbentuk sejak kecil, sehingga bersifat menetap dan stabil pada individu, namun ketangguhan dapat diubah melalui pelatihan (Maddi, 1987, 2004, 2006). Penelitian ini menemukan bahwa tidak terdapat perbedaan yang signifikan pada skor ketangguhan antara sebelum dan sesudah mengikuti pelatihan. Hal tersebut dapat disebabkan oleh beberapa faktor. Pertama, pelatihan ini menggunakan jangka waktu yang terlalu singkat antara pemberian pre-test dan post-test, sehingga menyebabkan peserta dapat mengingat dan mempelajari alat ukur yang digunakan sebelumnya (Bartone \& Hystad, 2010). Kedua, durasi pemberian pelatihan ketangguhan. Dalam penelitian sebelumnya, pelatihan ketangguhan diberikan sebanyak 10-15 sesi dan ditemukan terjadi peningkatan ketangguhan pada peserta (Maryam, Shohre, \& Javad, 2013; Tarkhan dkk., 2012), sedangkan pada penelitian ini pelatihan ketangguhan hanya terdiri dari 6 sesi, sehingga dapat memengaruhi hasil akhir pelatihan. Belum ada literatur yang mengkaji dan membahas mengenai keterkaitan antara durasi dan jumlah pemberian sesi terhadap peningkatan ketangguhan, sehingga hal ini dapat dijadikan rekomendasi untuk pelatihan selanjutnya. Ketiga, penurunan ketangguhan dan PWB pada saat follow-up memperkuat argumentasi bahwa meskipun skor ketangguhan dapat mengalami peningkatan setelah mengikuti pelatihan, namun setelah 6 bulan skor ketangguhan akan kembali seperti skor dasar (baseline) (Tierney \& Lavelle, 1997). Penurunan ketangguhan saat follow-up diikuti dengan penurunan terhadap PWB dikarenakan adanya hubungan positif antara ketangguhan dan PWB. Untuk mengantisipasi hal tersebut, Bartone dkk. (2010) 
menjelaskan pentingnya melakukan follow-up secara rutin dan pelatihan ulang untuk membuat efek atau dampak pelatihan bertahan lebih lama bagi peserta.

Berdasarkan hasil pengolahan data untuk masing-masing aspek dari ketangguhan, terdapat perbedaan signifikan antara aspek kontrol dan komitmen. Temuan ini memperkuat dugaan dari penelitian sebelumnya yang menyatakan bahwa kontrol dan komitmen merupakan aspek yang memiliki tingkat korelasi tinggi dibandingkan dengan aspek tantangan. Berbagai penelitian masih memperdebatkan bahwa aspek tantangan memiliki peluang untuk dieliminasi dari aspek ketangguhan karena hanya aspek komitmen dan kontrol yang secara sistematis berkaitan dengan kesehatan (Eschleman, Bowling, \& Alarcon, 2010; Florian, Mikulincer, \& Taubman, 1995; Funk, 1992).

Hasil uji korelasi menyatakan bahwa terdapat korelasi positif antara ketangguhan dan PWB. Hasil penelitian ini menjelaskan bahwa semakin tinggi karakteristik tangguh yang dimiliki seseorang, maka dapat meningkatkan PWB seseorang. Hasil penelitian ini mendukung penelitian serupa yang dilakukan di dalam dan luar negeri (Ausie, Wardani, \& Selly, 2017; Cerezo dkk., 2015). Jika dibandingkan pada partisipan yang dilibatkan dalam penelitian ini, yaitu pada mahasiswa dapat disimpulkan bahwa tidak terdapat perbedaan hubungan antara pelatihan ketangguhan dan PWB pada karakteristik sampel yang berbeda.

Pelatihan ketangguhan diberikan pada individu yang memiliki risiko tinggi terhadap permasalahan kesehatan dan penurunan kinerja profesionalitas yang terlibat dalam situasi yang tidak menyenangkan (tentara dan polisi), atau kehidupan individu yang terganggu karena kematian dan perceraian. Pelatihan ketangguhan juga bermanfaat bagi organisasi, meliputi karakteristik budaya organisasi, lingkungan, struktur, dan tekanan kerja dari organisasi (Maddi, Khosaba, \& Pammenter, 1999). Pelatihan ketangguhan yang diberikan kepada mahasiswa merupakan pencegahan yang membantu mahasiswa agar dapat menghadapi atau mengubah tantangan menjadi sebuah kesempatan untuk bertumbuh, berkembang, dan meningkatkan kesejahteraan.

Peningkatan PWB pada mahasiswa juga dipengaruhi oleh pemberian materi dalam pelatihan ini. Pelatihan ini berfokus pada pengetahuan (knowledge), keterampilan (skill), dan sikap (attitude) partisipan (Khoshaba \& Maddi, 1999). Pengetahuan dikembangkan dari pemberian materi dan penjelasan secara verbal dalam setiap sesi pada partisipan. Keterampilan dikembangkan melalui materi coping strategies yang tepat, relaksasi, dan aktivitas fisik. Dalam pelatihan ini, sikap dikembangkan melalui umpan balik yang diberikan pelatih dalam setiap sesi dan refleksi yang dibuat partisipan di akhir sesi 1 hingga 6 (Khoshaba \& Maddi, 1999; Maddi, 1999). Pelatihan ini 
juga memberikan buku panduan yang berisi penjelasan dan contoh dari komponen ketangguhan dan $P W B$ pada setiap sesi (Khoshaba \& Maddi, 1999).

Terdapat tiga aspek dari pelatihan ketangguhan, yaitu rekonstruksi situasi, dukungan sosial, dan self-care. Pelatihan ketangguhan bertujuan untuk meningkatkan kemampuan koping yang tepat, sehingga mampu mencari solusi ketika diperhadapkan pada permasalahan, perubahan, atau tantangan (Khoshaba \& Maddi, 2001). Peserta diajarkan untuk melakukan rekonstruksi situasi melalui proses imajinasi untuk mengembangkan perspektif dan pemahaman yang mendalam mengenai kondisi atau keadaan yang dialami. Hal tersebut membantu peserta untuk menyusun rancangan tindakan di masa yang akan datang (sesi 3 dan 4). Peserta juga diajarkan untuk fokus merefleksikan tanda emosi negatif pada tubuh (sensasi ketegangan pada tubuh) (sesi 2 dan 5). Pelatihan ketangguhan juga mampu meningkatkan interaksi sosial antar individu melalui strategi mengatasi konflik antar individu, kemampuan berkomunikasi, dan mendengar ( care menekankan untuk menjaga respons-respons organik tubuh ketika menghadapi permasalahan dan mencari solusi yang tepat, sehingga terhindar dari permasalahan kesehatan (sesi 4 dan 5).

Beberapa keterbatasan dalam penelitian ini adalah penyebaran partisipan belum merata dan hanya melibatkan 20 partisipan. Penelitian selanjutnya dapat memperluas dan memperbanyak jumlah partisipan yang dilibatkan dalam pelatihan. Penelitian ini hanya memberikan materi sebanyak enam sesi, sehingga pada penelitian selanjutnya dapat mengemas materi sekitar $10-15$ sesi dan melihat perbedaan antara ketangguhan dan PWB sebelum dan sesudah mengikuti pelatihan. Penelitian ini mendeskirpsikan hasil ketangguhan dan PWB sebelum, sesudah, dan setelah tiga minggu mengikuti pelatihan tanpa adanya pendampingan, pengawasan, atau pemberian pelatihan ulang. Pada penelitian mendatang, dapat berfokus untuk mengetahui perbedaan ketangguhan dan PWB dengan melakukan pengawasan dan pemberian pelatihan ulang selama masa evaluasi lanjutan. Penelitian ini juga tidak melibatkan randomisasi kelompok kontrol, sehingga pada penelitian mendatang dapat melibatkan kelompok kontrol sebagai pembanding, sehingga data yang dihasilkan lebih mendalam. Selain itu, penelitian ini belum mempertimbangkan faktor-faktor lain yang dapat memengaruhi ketangguhan dan PWB, sehingga pada penelitian selanjutnya dapat mempertimbangkan faktor lain yang berperan pada ketangguhan dan PWB. 


\section{SIMPULAN DAN SARAN}

\section{Simpulan}

Kesimpulan penelitian ini adalah terdapat perbedaan yang signifikan pada PWB antara sebelum dan sesudah mengikuti pelatihan ketangguhan. Secara khusus, pelatihan ketangguhan dapat meningkatkan ketangguhan partisipan pada tataran pengetahuan dan sikap. Studi ini juga menunjukkan bahwa terdapat hubungan yang signifikan antara ketangguhan dan PWB. Merujuk pada hasil lanjutan, dapat disimpulkan bahwa pelatihan ketangguhan dapat mempertahankan peningkatan skor PWB peserta dalam jangka waktu yang singkat, sehingga untuk mengetahui efektivitas pelatihan ketangguhan pada PWB dalam jangka waktu yang lama dibutuhkan penelitian mendalam.

\section{Saran Teoretis}

Saran untuk penelitian selanjutnya adalah lebih mendalami pengaruh ketangguhan terhadap PWB. Saran untuk pelatihan selanjutnya adalah pelatihan dapat melibatkan partisipan yang lebih luas dengan karakteristik yang berbeda dari penelitian ini, sehingga dapat memperluas kajian teori seputar ketangguhan dan PWB. Kedua, penelitian selanjutnya dapat diberikan dengan waktu dan sesi yang lebih banyak, sehingga materi dan teknik-teknik yang diajarkan lebih beragam untuk menambah pengetahuan dan pemahaman peserta. Ketiga, penelitian selanjutnya dapat mengkaji dan membandingkan hasil ketangguhan dan PWB saat sebelum, sesudah, dan setelah enam bulan mengikuti pelatihan yang diikuti dengan pemantauan dan pemberian pelatihan ulang secara singkat. Keempat, penelitian selajutnya dapat melibatkan kelompok kontrol dan kelompok eksperimen untuk melihat efektivitas dari pelatihan ketangguhan terhadap PWB. Penelitian selanjutnya juga diharapkan dapat menganalisa dan mempertimbangkan berbagai faktor lain yang dapat memengaruhi PWB seseorang. Selanjutnya, diharapkan sampel pada penelitian dapat diperluas pada kelompok dengan karakteristik dan natur organisasi yang berbeda.

\section{Saran Praktis}

Penelitian ini diharapkan membawa dampak positif bagi mahasiswa yang juga tergabung dalam UKM untuk meningkatkan PWB melalui ketangguhan. Beberapa teknik yang dapat diaplikasikan mahasiswa dari pelatihan ini adalah relaksasi dan teknik pemecahan masalah dengan menggunakan pendekatan SMART dan SWOT. Teknik ini dapat digunakan mahasiswa untuk 
meningkatkan kesadaran dalam menghadapi masalah, serta menentukan tujuan hidup yang lebih spesifik dan realistis. Selain itu, proses pengawasan diharapkan dapat dilakukan oleh pembina atau pendamping untuk mengulang materi dan strategi yang sudah diajarkan selama proses pelatihan.

\section{UCAPAN TERIMA KASIH}

Ucapan terima kasih ditujukan kepada UKM Paduan Suara masa bakti tahun 2018-2019 di Universitas Surabaya yang telah berpartisipasi dalam studi ini.

\section{REFERENSI}

Alfred, G., Hammer, J., \& Good, G. (2014). Male student veterans: Hardiness, psychological well being and masculine norms. Psychology of Men and Masculinity, 15, 95-99.

Amiruddin. (2017). Analisis faktor-faktor penyebab tingkat kejadian stres pada mahasiswa fakultas kedokteran Universitas Hasanuddin angkatan 2015 (Skripsi tidak dipublikasikan). Universitas Hasanuddin, Indonesia.

Anggoro, A. (2016). Hubungan keaktifan berorganisasi dengan prokrastinasi akademik dan indeks prestasi kumulatif mahasiswa tahun ketiga fakultas kedokteran Universitas Lampung (Skripsi tidak dipublikasikan). Universitas Lampung, Indonesia.

Ausie, R., Wardani, R., \& Selly. (2017). Hubungan antara hardiness dan kesejahteraan psikologis pada calon bintara Korps Wanita Angkatan Darat (KOWAD) di pusat pendidikan KOWAD Bandung. Humanitas, 1(3), 10.

Bartone, P. T., \& Hystad, S. W. (2010). Increasing mental hardiness for stress resilience in operational settings. Dalam P. T. Bartone, B. H. Johnsen, J. Eid, J. M. Violanti, \& J. C. Laberg (Ed.), Enhancing human performance in security operations (hal. 257-272). Springfield, IL: Charles C. Thomas.

Beleaua, R. E., \& Cocoradă, E. (2016). Procrastination, stress and coping in students and employees. Romanian Journal of Experimental Applied Psychology, 7(1), 1-6.

Bonanno, G. (2004). Loss, trauma, and human resilience: Have we underestimated the human capacity to thrive after extremely aversive events? The American Psychologist, 59, 20-28. 
Cahyaningtyas, A. Y. (2010). Perbedaan kecerdasan emosional berdasarkan status keikutsertaan dalam organisasi ekstrakulikuler pada mahasiswa di kebidanan (Skripsi tidak dipublikasikan). Universitas Sebelas Maret, Indonesia.

Cerezo, A., Galian, A., Tarroja, M., Mañalac, G., \& Ysmael, M. (2015). Breaking news: How hardiness moderates the impact of burnout on the PWB of Filipino journalists covering disasters and emergencies. Philippine Journal of Psychology, 48(2), 19.

De Ridder, D., Lensvelt-Mulders, G., Finkenauer, C., Stok, F. M., \& Baumeister, R. F. (2012). Taking stock of self-control: A meta-analysis of how trait self-control relates to a wide range of behaviors. Personality and Social Psychology Review, 16(1), 76-99. doi: $10.1177 / 1088868311418749$

Eschleman, K., Bowling, N., \& Alarcon, G. (2010). A meta-analytic examination of hardiness. International Journal of Stress Management, 17(4), 277-366. doi: 10.1037/a0020476

Finkel, E. J., \& Campbell, W. K. (2001). Self-control and accommodation in close relationships: An interdependence analysis. Journal of Personality and Social Psychology, 81(2), 263-277. doi: 10.1037//0022-3514.81.2.263

Florian, V., Mikulincer, M., \& Taubman, O. (1995). Does hardiness contribute to mental health during a stressful real-life situation? The roles of appraisal and coping. Journal of Personality and Social Psychology, 68, 687-695. doi: 10.1037/0022-3514.68.4.687

Freire, C., Ferradás, M. M., Valle, A., Núñez, J. C., \& Vallejo, G. (2016). Profiles of PWB and coping strategies among university students. Frontiers in Psychology, 7, 1-11. doi: 10.3389/fpsyg.2016.01554

Funk, S. (1992). Hardiness: A review of theory and research. Health Psychology, 11(5), 335-345. doi: 10.1037/0278-6133.11.5.335

Garcia, D., \& Siddiqui, A. (2009). Adolescents' affective temperaments: Life satisfaction, interpretation, and memory of events. The Journal of Positive Psychology, 4(2), 155-167. doi: 10.1080/17439760802399349

Hussain, I., \& Sultan, S. (2010). Analysis of procrastination among university students. Procedia Social and Behavioral Sciences, 5, 1897-1904. doi: 10.1016/j.sbspro.2010.07.385

Jayervand, H., Ahdi, H., Mazaheri, M., Talebi, H., \& Manshaee, Q. (2013). Prediction of suicide ideation based on PWB and religious spiritual determinants among the individuals with attempted suicide. Journal of Basic and Applied Scientific Research, 3(8), 587-590. 
Khoshaba, D. M., \& Maddi, S. R. (1999). Early experiences in hardiness development. Consulting Psychology Journal, 51, 106-116.

Khoshaba, D. M., \& Maddi, S. R. (2001). HardiTraining. Newport Beach, CA: Hardiness Institute.

Kobasa, S. C., Maddi, S. R., \& Kahn, S. (1982). Hardiness and health: A prospective study. Journal of Personality and Social Psychology, 42(1), 168-177. doi: 10.1037/0022-3514.42.1.168

Maddi, S. R. (1987). Hardiness training at illinois bell telephone. Open Acces Library Journal, 3(8), 101-115.

Maddi, S. R. (1999). The personality construct of hardiness: I, effect on experiencing, coping and strain. Consulting psychology Journal, 51, 83-94.

Maddi, S. R. (2004). Hardiness: An operationalization of existential courage. Journal of Humanistic Psychology, 44, 279-298.

Maddi, S. R. (2005). On hardiness and other pathways to resilience. American Psychologist, 60(3), 261-262. doi: 10.1037/0003-066X.60.3.261

Maddi, S. R. (2006). Hardiness: The courage to grow from stresses. Journal of Positive Psychology, 1, 160-168. doi: 10.1177/0022167804266101

Maddi, S. R., Khosaba, D. M., \& Pammenter, A. (1999). The hardy organization: Success by turning change to advantages. Consulting Psychology Journal, 51, 117-124.

Maltin, E. R. (2011). Workplace commitment and employee well-being: A meta-analysis and study of commitment profiles (Tesis tidak dipublikasikan). The University of Western Ontario, Canada.

Maryam, G. A., Shohre, G. S., \& Javad, K. (2013). Effectiveness of hardiness training on anxiety and quality of life of pregnancy women. Procedia - Social and Behavioral Sciences, 84, 1785-1789.

Mathis, M., \& Lecci, L. (1999). Hardiness and college adjustment: Identifying students in need of services. Journal of College Student Development, 40, 305-309.

Mayasari, L. (2007). Prokrastinasi akademik pada mahasiswa aktivis organisasi (Skripsi tidak dipublikasikan). Universitas Muhammadiyah, Indonesia.

Nayyeri, M., \& Aubi, S. (2011). Prediction well-being on basic components of hardiness. Procedia - Social and Behavioral Sciences, 30, 1571-1575. doi: 10.1016/j.sbspro.2011.10.305

Ofori, I. N., Addai, P., Avor, J., \& Quaye, M. G. (2018). Too much academic stress: Implication on interpersonal relationships and PWB among final year University of Ghana student. Asian Journal of Education and Social Studies, 2(3), 1-7. doi: 10.9734/AJESS/2018/43193 
Proctor, C., Linley, P. A., \& Maltby, J. (2009). Youth life satisfaction measures: A review. The Journal of Positive Psychology, 4(2), 128-144. doi: 10.1080/17439760802650816

Rangkuti, F. (2004). Analisis SWOT teknik membedah kasus bisnis. Jakarta: Gramedia Pustaka Utama.

Righetti, F., \& Finkenauer, C. (2011). If you are able to control yourself, I will trust you: The role of perceived self-control in interpersonal trust. Journal of Personality and Social Psychology, 100(5), 874-886. doi: 10.1037/a0021827

Ryff, C. (1989). Happiness is everything, or is it? Explorations on the meaning of PWB. Journal of Personality and Social Psychological, 57(6), 1060-1081.

Sahari, S. H., Yaman, Y. M., \& Awang-Shuib, A. (2012). Environmental stress among part time students in Sarawak. Procedia-Social and Behavioral Sciences, 36, 96-102.

Sandvik, A. M., Hansen, A. L., Hystad, S. W., Johnsen, B. H., \& Bartone, P. T. (2015). Psychopathy, anxiety, and resiliency - Psychological hardiness as a mediator of the psychopathy-anxiety relationship in a prison setting. Personality and Individual Differences, 72, 30-34. doi: 10.1016/j.paid.2014.08.009

Skomorovsky, A., \& Sudom, K. (2011). Role of hardiness in the PWB of Canadian forces officer candidates. Military Medicine, 176(1), 7-12. doi: 10.7205/milmed-d-10-00325

Sugiyono. (2004). Statistika untuk penelitian. Bandung: Alfabeta.

Suleman, Q., Hussain, I., Shehzad, S., Syed, M., \& Raja, S. (2018). Relationship between perceived occupational stress and PWB among secondary school heads in Khyber Pakhtunkhwa, Pakistan. PLoS ONE, 13(12), 1-22. doi: 10.1371/journal.pone.0208143

Tangney, J. P., Baumeister, R. F., \& Boone, A. L. (2004). High self-control predicts good adjustment, less pathology, better grades, and interpersonal success. Journal of Personality, 72(2), 271-324.

Tarkhan, M., Safdari, S., Fallah, S., Paknahad, Z., Rezaei, A., Nezamiv, ... Sargolzaei, M. (2012). The effect of hardiness training of self esteem and social adjustment among addicted men in rudsar of Iran. Indian journal of Fundamental and Applied Life Sciences, 2(3), 94-99.

Tierney, M. J., \& Lavelle, M. (1997). An investigation into modification of personality hardiness in staff nurses. Journal of Nursing Staff Development, 13, 212-217.

Yikealo, D., Tareke, W., \& Karvinen, I. (2018). The level of stress among college students: A case in the college of education, Eritrea Institute of Technology. Open Science Journal, 3(4), 1-18. 